\title{
PROTOTIPE PROSES PEMBELAJARAN MENGGUNAKAN ILEARNING PADA STKIP ARRAMANIYAH TANGERANG
}

\author{
Nora Fitriawati ${ }^{1}$, Arief Herdiansah ${ }^{2}$ \\ 1 Universitas Bina Nusantara / Fakultas Teknik, Prodi Teknik Informatika \\ Jl. Kyai H. Syahdan No.9, Kemanggisan, DKI Jakarta 11480, TLP 5345830 \\ 2Universitas Muhammadiyah Tangerang / Fakultas Teknik, Prodi Informatika \\ JI. Perintis Kemerdekaan 1/33 Cikokol Kota Tangerang TLP. 55793251,
}

Email: 1Nora.fitriawati@Binus.edu , 2arief_herdiansah@umt.ac.id

\begin{abstract}
ABSTRAK
Pembelajaran yang efektif merupakan harapan bagi semua instansi pendidikan tidak terkecuali bagi STKIP Arramaniyah sebagai salah satu pelopor pendidikan yang bertanggung jawab untuk untuk menjadi Guru yang berkualitas dan mengerti teknologi informasi. iLearning adalah suatu suatu sistem pembelajaran terpadu yang diterapkan untuk membentuk pendidikan agar menjadi lebih baik dan berkualitas. Penggunaan ilearning banyak memberikan kelebihan namun ada masalah yang belum terselesaikan dan menyebabkan dosen kesulitan untuk mendapatkan informasi tentang mahasiswa dalam pembelajaran iLearning. Oleh karena itu dikembangkan alat monitoring untuk menganalisis interaksi mahasiswa dalam perkuliahan, melalui Dashbord Business Intelligence dan teknologi Online Analytical Processing (OLAP.) B dalam pembelajaran iLearning dapat menyajikan study kasus tentang bagaimana menerapan teknologi dalam database sistem iLearning.
\end{abstract}

Kata Kunci : Dashboard, Online Analytical Processing (OLAP.), iLearning.

\begin{abstract}
Effective learning is a hope for all educational institutions is no exception for STKIP Arramaniyah as one of the pioneers of education that is responsible for to become a qualified teacher and understand information technology. iLearning is an integrated learning system that is applied to shape education to become better and better quality. The use of ilearning gives many advantages but there are problems that have not been resolved and cause lecturer difficulty to get information about students in learning iLearning. Therefore developed monitoring tools to analyze student interaction in lectures, through Dashbord Business Intelligence and OLAP in iLearning learning can present case study on how to deploy technology in iLearning system database.
\end{abstract}

Keywords: Dashboard, Online Analytical Processing (OLAP.), ILearning. 


\section{PENDAHULUAN}

Pendidikan merupakan sebuah program yang melibatkan sejumlah komponen yang bekerja sama dalam sebuah proses untuk mencapai tujuan yang diprogramkan.

Melihat latar belakang STKIP Arramaniyah sebagai sekolah tinggi yang mendidik calon Guru berkualitas, dirasakan perlu adanya suatu inovasi yang dapat membangkitkan sumber daya dosen yang ada menjadi lebih baik, yaitu inovasi pembelajaran yang dapat meningkatkan kualitas pembelajaran menjadi lebih optimal dan lebih efektif terhadap mahasiswa/i sehingga pembelajaran yang dilakukan dapat memberikan efek yang baik bagi perkembangan mahasiswa dan juga memberikan nilai tersendiri baik bagi dosen dan juga STKIP sebagai salah satu kampus di bidang ilmu pendidikan dapat mencetak lulusan yang memiliki softskill secara lugas dan kooperatif di dengan mengenal ilmu komputer dan sistem informasi. untuk memenuhi kebutuhan terhadap tenaga-tenaga muda yang terampil dan profesional di bidang Pendidikan yang memahami teknologi informasi. Berkaitan dengan hal tersebut peneliti ingin mengembangkan sistem pembelajaran yang ada dengan inovasi pembelajaran iLearning yang dilakukan pada kampus-kampus besar.

Sistem iLearning merupakan sistem pembelajaran terpadu yang diterapkan merupakan salah satu bentuk untuk meningkatkan mutu menuju suatu pendidikan yang modern dan berkualitas ${ }^{[2]}$

Sistem iLearning (integrated Learning) atau dalam bahasa indonesia disebut sistem pembelajaran terpadu yang diterapkan merupakan salah satu bentuk untuk meningatkan mutu menuju suatu pendidikan yang modern dan berkualitas. [7]

\subsection{Identifikasi Masalah}

Dalam proses pemberian metode pembelajaran di STKIP Arramaniyah ada bebarapa kendala yang dihadapi:

1. Belum tersedia sebuah sistem pembelajaran yang memberikan kemudahan untuk dosen dalam memantau proses pembelajaran kepada mahasiswanya.

2. Metode pembelajaran yang digunakan saat ini belum dapat mendukung komunikasi aktif atau masih pasif terhadap respon mahasiswa.

3. Metode sistem pembelajaran pada STKIP Arramaniyah belum seirama dan mengikuti perkembangan sistem informasi di bidang ilmu Pendidikan.

4. Ada keinginan keinginan manajemen untuk merubah sistem pembelajaran mahasiswa STKIP Arramaniyah, dari konvensional menjadi sistem pembelajaran berbasis komputer melalui media iLearning.

\subsection{Batasan Masalah}

penelitian ini dibatasi dengan batasan sebagai berikut:

1. Membangun dan menerapkan suatu inovasi pembelajaran digital dengan iLearning untuk membantu sistem pembelajaran pada STKIP Arramaniyah dalam hal interaksi antara Mahasiswa dan Dosen pada proses kegiatan belajar mengajar.

2. Membuat dan melakukan survei untuk mengetahui ukuran dari kualitas penilaian dan efektivitas pembelajaran dalam ketertarikan seluruh aspek yang ada pada sistem iLearning oleh mahasiswa dan melakukan survei untuk melihat peran iLearning sebagai salah satu bagian dari Teknologi Informasi pembelajaran elektronik.

\subsection{Rumusan Masalah}

Permasalahan penelitian dapat dirumuskan sebagai berikut:

1. Bagaimana sebuah inovasi pembelajaran berbasis sistem informasi yang dibangun dapat digunakan untuk prose interaksi antara guru dan dapat mengetahui seberapa besar minat, keaktifan pengguna dalam mengikuti pelajaran?

2. Bagaimana survei yang dibuat dapat menghasilkan informasi yang dapat mengukur kualitas dan efektifitas pembelajaran mahasiswa dalam ketertarikan yang terdapat dalam sistem iLearning yang dikembangkan?

\section{LANDASAN TEORI}

\subsection{Tinjauan Pustaka}

\subsubsection{Definisi Media ilearning}

iLearning berarti sebuah metode pembelajaran dengan menggunakan jasa bantuan perangkat elektronik, khususnya perangkat komputer, karen itu ilearning 
sering disebut pula dengan istilah online course [1]

Sistem atau konsep pendidikan yang memanfaatkan teknologi informasi dalam proses belajar mengajar dapat disebut sebagai suatu iLarning. iLearning dalam arti luas bisa mencakup pembelajaran yang dilakukan di media elektronik (internet), baik secara formal maupun informal. iLearning secara formal, misalnya pembelajaran dengan kurikulum, silabus, mata pelajaran, dan tes yang telah diatur dan disusun berdasarkan jadwal yang telah disepakati pihak-pihak terkait.

Jadi Pembelajaran iLearning Media adalah suatu inovasi pada kegiatan belajar dan mengajar dengan menggunakan satu kesatuan perangkat teknologi informasi dan juga metode yang telah ditentukan secara prosedur untuk meningkatkan efektifitas pembelajaran yang memberikan solusi pembelajaran dengan memanfaatkan Teknologi Informasi dan Komunikasi sehingga belajar menjadi lebih menyenangkan karena memiliki konsep belajar, bermain, berdoa dan bekerja

\subsubsection{Prototipe}

Model pengembangan sistem prototipe merupakan model pengembangan pengembangan perangkat lunak (software) yang dapat dimembuat sistem dikembangkan dengan cara cepat dan sesuai dengan kebutuhan pengguna serta teruji dengan baik karena pengujian terhadap model kerja dari aplikasi baru melalui proses interaksi dan berulangulang. [6]

\subsubsection{Kualitas Pembelajaran}

Isilah kualitas berasal dari bahasa inggris (Quality) dan sepadan dengan kata mutu dalam bahasa Indonesia, merupakan istilah yang sudah tidak asing atau dikenal dalam kehdupan sehari-hari. Kata ini biasanya didahului atau dibarengi dengan kata lain, seperti kualitas ekspor, kualitas impor, kualitas ke imanan, kualitas kecerdasan, guru yang berkulitas, siswa yang berkualitas, dan lain sebagainya. Jadi kualitas adalah tingkatan atau baik buruknya sesuatu baik yang berupa benda atau manusia. Dalam kamus besar bahasa Indonesia (DEPDIKBUD, 1983:179) kualitas adalah ukuran baik buruk, mutu, taraf, kadar, atau derajat dari kecerdasan kepandaian dan sebagainya. ${ }^{[4]}$

\subsection{Tinjauan Studi}

Berikut ini adalah beberapa penelitian terdahulu yang terkait dengan topik arsip digital, antara lain :

1. Penelitian oleh Untung Rahardja, Dewi Immaniar. iLearning Metode Efektif Untuk Sekolah Tinggi. Jurnal Perguruan Tinggi Rahaja ISSN: 1978 8282Vol. 7 No.3 - Mei 2014[8]. Penelitian ini Kemajuan ilmu teknologi informasi pertumbuhan IPTEK yang semakin pesat mendorongperkembangan teknologi dalam bidang pendidikan saat ini seperti yang terlihat dari tren teknologi bahwa teknologi internet telah berevolusi.Tujuannya untuk proses pembelajaran iLearning yang terdapat pada artikel ini dapat membantu menciptakan pembelajaran yang mandiri dan interaktif.

2. Penelitian olah Mohammad Hassan Falakmasir Shahrouz Moaven Hassan, Abolhassan,. Business Intelligence in E-Learning, International Journal of Human-Computer Studies, vol. 65, no. 2, pp. 125-149, 2011. [5]

platform e-learning banyak digunakan universitas dan institusi pendidikan lainnya disatu sisi, kekurangan alat untuk melakukan, mengukur menilai, dan mengevaluasi kinerja peserta didik di Aktivitas pendidikan membuat para pendidik gagal menjamin keberhasilan proses belajar.

Disisi lain, ketatnya struktur materi pembelajaran mencegah siswa untuk memperolehnya

pengetahuan berdasarkan gaya belajar mereka. Karena itu, mengembangkan alat monitor dan menganalisis interaksi peserta didik dengan lingkungan e-learning sangat diperlukan. Bisnis intelligence (BI) dan teknologi On Line Analytical Processing (OLAP) digunakan untuk memantau dan menganalisis perilaku peserta didik dan kinerja di lingkungan e-learning.

\section{METODOLOGI PENELITIAN 3.1 Jenis Penelitian}

Penelitian ini merupakan penelitian dan pengembangan yang memiliki keterlibatan intens peneliti dengan masalah dan objek penelitian. Titik berat penelitian ini adalah pada perubahan dan mengatasi masalah nyata di objek penelitian, sehingga terdapat kontribusi nyata dan langsung terhadap objek 
penelitian dalam mengatasi masalah tersebut.

\subsection{Metode Pemilihan Populasi}

Yang menjadi populasi penelitian ini adalah Mahasiswa, Mahasiswa yang dimaksud adalah Mahasiswamahasiswadi STKIP Arramaniyah yang masih aktif kuliah dengan berbagai jurusan, seperti: jurusan Biologi sebanyak 125 orang, PKn sebanyak 215 dan PGSD sebanyak 185 orang, dan yang mengikuti yang mengikuti mata kuliah Metodologi Pendidikan dan Pengantar IImu Komputer.

\subsection{Metode Sample}

Pengambilan sampel dapat digunakan dengan pendekatan "Sample Random Sampling" Perhitungan jumlah sampel dari populasi yang berdistribusi normal dapat dilakukan dengan metode pemilihan sampel dengan rumus Slovin, sebagai berikut :

\section{Dimana :}

$$
n=\frac{N}{\left(1+N \cdot e^{2}\right)}
$$

$\mathrm{n}=$ ukuran Sampel

$\mathrm{N}=$ ukuran populasi

$\mathrm{e}^{2}=$ Persen kesalahan yang diinginkan atau ditolerir (digunakan $10 \%$ )

Perhitungan pengambilan sampel masing-masing untuk tingkat jurusan sebagai berikut:

Tabel III-1. Tabel Sampel Jurusan

\begin{tabular}{|c|c|c|c|}
\hline Jurusan & $\begin{array}{c}\text { Tingkat } \\
\text { Populasi }\end{array}$ & $\begin{array}{c}\text { Perhitungan } \\
\text { Sampel }\end{array}$ & Sampel \\
\hline Biologi & 125 & $125 /\left(1+125 \cdot(0.1)^{2}\right)$ & 56 \\
\hline PKn & 215 & $215 /\left(1+215 \cdot(0.1)^{2}\right)$ & 68 \\
\hline PGSD & 185 & $185 /\left(1+185 .(0.1)^{2}\right)$ & 65 \\
\hline
\end{tabular}

Tabel III-2. Sample Mata Kuliah

\begin{tabular}{|c|c|c|c|}
\hline Mata Kuliah & $\begin{array}{c}\text { Tingkat } \\
\text { Populasi }\end{array}$ & $\begin{array}{c}\text { Perhitungan } \\
\text { Sampel }\end{array}$ & Sampel \\
\hline $\begin{array}{c}\text { Pengantar } \\
\text { Ilmu } \\
\text { Komputer }\end{array}$ & 50 & $50 /\left(1+50 .(0.1)^{2}\right)$ & 33 \\
\hline $\begin{array}{c}\text { Metodologi } \\
\text { Pendidikan }\end{array}$ & 50 & $50 /\left(1+50 .(0.1)^{2}\right)$ & 33 \\
\hline
\end{tabular}

Metode Pengumpulan data yang dijalankan dalam penelitian ini adalah:

1. Metode Wawancara

Proses Tanya jawab dilakukan langsung kepada mahasiswa/l selaku responden di STKIP Arramaniyah.
2. Metode Survey

Survey dilakukan ke pihak-pihak yang berkaitan dengan iLearning antara lain: dosen, mahasiswa/i.

3. Metode Observasi

Observasi dilakukan langsung ke kampus STKIP Arramaniyah yang menjadi lokasi penelitian guna memperoleh data dan keterangan

\subsection{Desain Penelitian}

Desain penelitian merupakan kerangka kerja yang digunakan untuk melakukan penelitian. Desain dari penelitian yang dilakukan sebagaimana Gambar III-1.

Jika diuraikan maka menjelaskan tentang perkuliahan di bagi menjadi pra perkuliahan iLearnig dan Pelaksanaan Perkuliahan iLearning.

Maksud dari Pra Perkuliahan iLearning untuk mengetahui sejauh mana peserta menguasai media pembelajaran iLearning serta media komunikasi yang akan digunakan untuk perkuliahan iLearning.

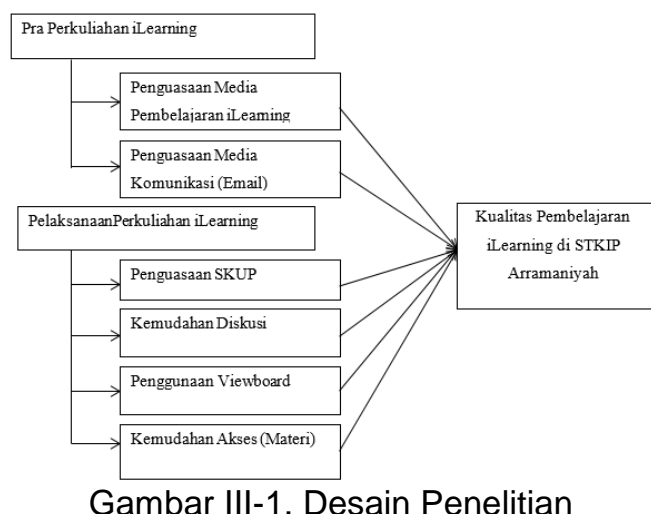

\section{PEMBAHASAN HASIL PENELITIAN}

\subsection{Tampilan Menu Utama}

Tampilan awal adalah memberikan informasi kepada Mahasiswa tentang perkulianan dengan menggunakan iLearning Media. 


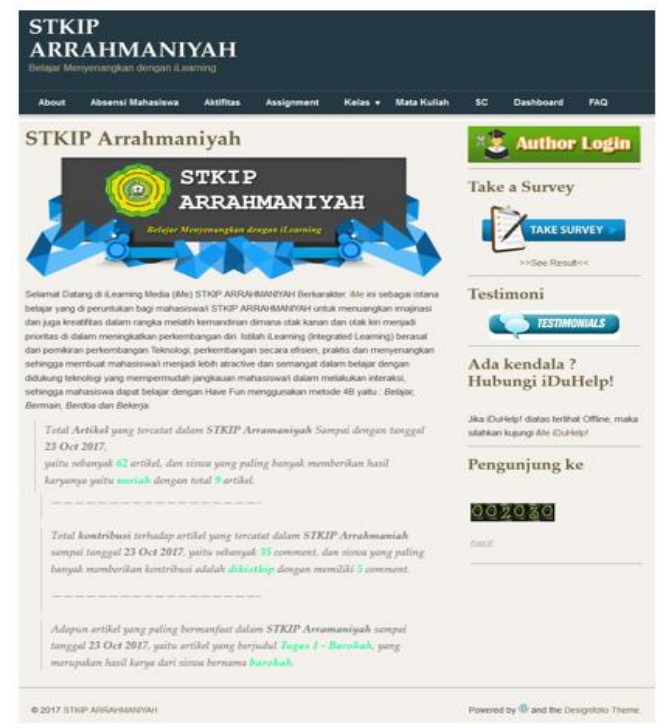

Gambar IV-1 Tampilan Menu Utama

\subsection{Tampilan Menu Login}

Sebelum masuk kedalam sistem, user harus Login terlebih dahulu. Setelah user berhasil login kedalam sistem, maka akan tampil tampilan sebagai berikut:

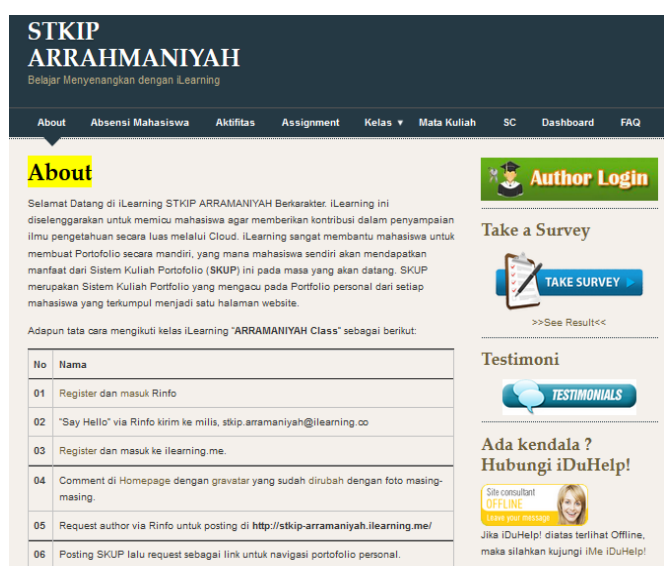

Gambar IV-2 Tampilan About

\subsection{Dashboard Utama}

Dashboard pada penelitian ini menampilkan total artikel yang sudah di upplood Mahasiswa, Total Commend dan Total Mahasiswa Aktif, data ini berguna bagi dosen, mahasiswa dan orang tua siswa untuk memberikan informasi tentang keaktifan Mahasiswa di kelas selama perkuliahan berjalan.

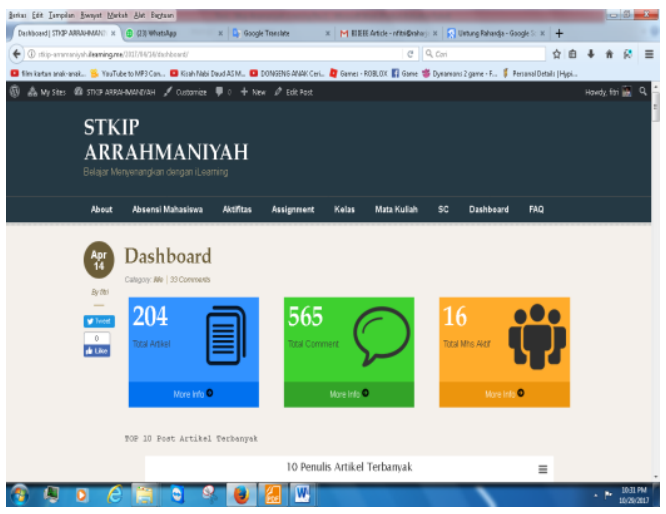

Gambar IV-3 Tampilan Dashboard Utama

\subsection{Dasboard Penulis Artikel Terbanyak}

Hasil Pengembangan aplikasi dalam penelitian ini dapat menampilkan dashboard 10 mahasiswa penulis artikel terbanyak, artikel yang dikirimkan bebas namun tidak terlepas dari mata kuliah yang di ampuh yaitu Pengenalan IImu Komputer, baik di dunia pendidikan, psikologi anak, maupun bisnis online yang saat ini sedang banyak di minati, tujuan pengiriman artikel ini untuk menambah wawasan mahasiswa khusus nya di bidang teknologi informasi.

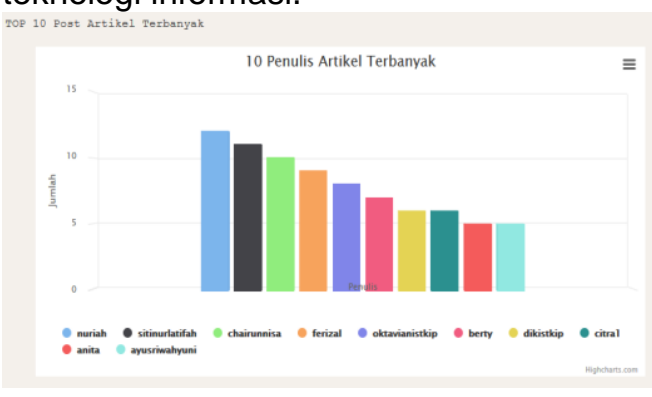

Gambar IV-4. Tampilan Dashboard Penulis Artikel Terbanyak

\subsection{Dasboard Komentator Artikel \\ Terbanyak}

Dalam Dashbord ini 10 mahasiswa komentar paling banyak dalam Pembelajara iLearning, mahasiswa ini bisa comment tentang materi yang disampaikan dosen, maupun artikel yang dikirimkan oleh teman-teman dalam kelas. 


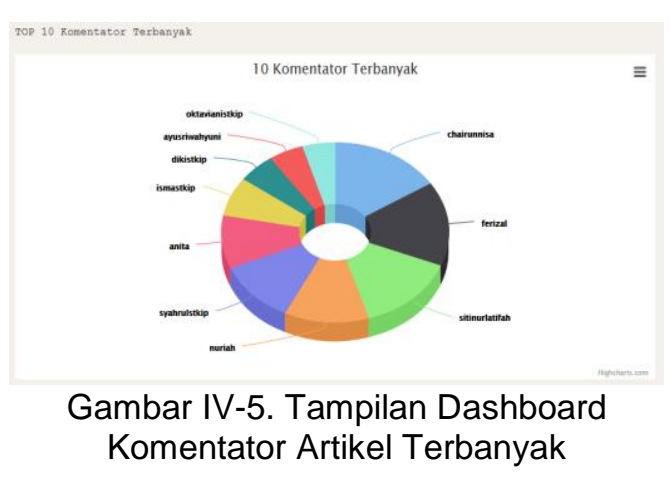

\subsection{Fitur Absensi Mahasiswa/i}

Pada perkuliahan menggunakan iMe ini, absensi mahasiswa di jalankan tidak manual lagi namun sudah dapat digunakan pada iMe STKIP Arramaniyah, sehingga absen mahasiswa dapat di pantau oleh dosen dan orang tua mahasiswa, namun dikelas ini belum tentukan standart untuk mengikuti ujian, bertahap akan dilakukan standart dan ketentuan absensi. Berikut tampilan menu absensi Mahasiswa:
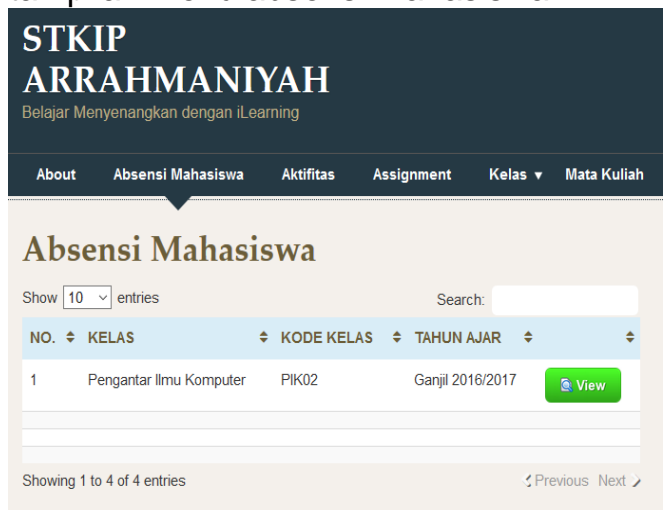

Gambar IV-6. Tampilan Menu Absensi Mahasiswa/i

\subsection{Pengujian Sistem ISO 9106}

Untuk menilai kualitas sistem menggunakan ISO 9106 menggunakan enam karakteristik [3] peneliti membuat formulir user acceptance test yang terdiri 22 peryataan untuk diuji dan dijawab oleh responden/pengguna sebagaimana Tabel IV.1.

Tabel IV-1 Pengujian ISO 9126

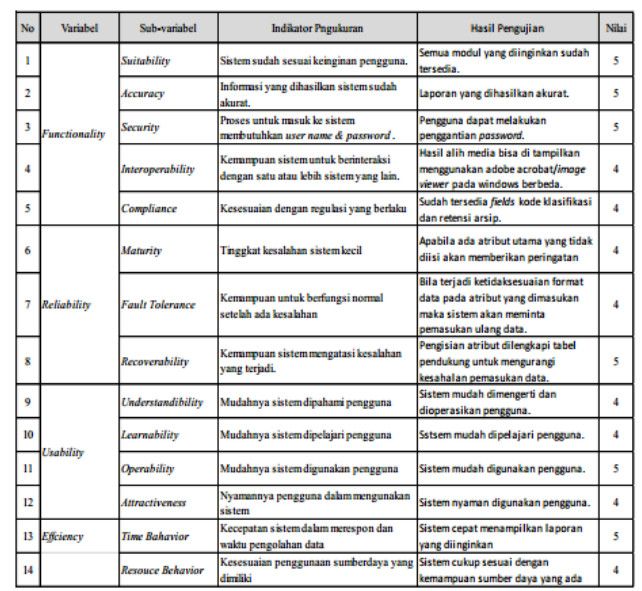

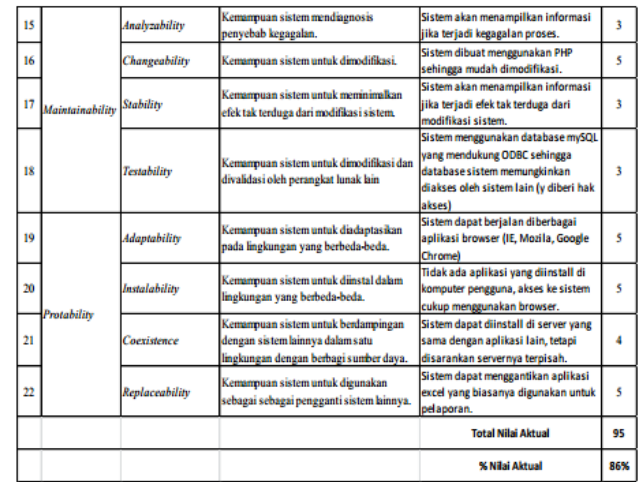

Hasil pengujian menggunakan standarisasi ISO 9126 sebagaimana gambar diatas menghasilkan tingkat kepuasan pengguna $86 \%$ (sangat baik).

\section{KESIMPULAN}

Berdasrakan uraian-uraian pada penulisan diatas, kesimpulan yang peneliti sampaikan sebagai berikut:

1. Implementasi perkuliahan yang diterapkan dengan iLearning Media dengan menambahkan dashboard untuk kontrol aktifitas kelas dan mahasiswa, membuat mahasiswa sangat antusias dan senang menjalankan kegiatan perkuliahan, itu membuat komunikasi antara dosen dan mahasiswapun berjalan lebih baik sehingga dapat membuktikan proses pembelajaran sangat efektif.

2. Sistem iLearning yang di implementasikan dapat mengukur keaktifan mahasiswa melalui dashboard yang di tampilkan sehingga memberikan semangat mahasiswa untuk mencapai nilai terbaik.

\section{DAFTAR PUSTAKA}

[1] Andri, Muhammad. 2008. Utilization of Information Technology in the Development of Learning Media. Teknik Elektro, Universitas Gajah Mada. Yogyakarta.

[2] Henderi, Muhamad Yusup, Yulika Ayu Rantama (2013), Penggunaan Metode iLearning Untuk Meningkatkan Kualitas Pembelajaran di Perguruan Tinggi, Tangerang, STMIK Raharja, CCIT.

[3] IEC (2000), International Standard ISO/IEC 9126-1 Information Technology Software Product Quality. 
[4] Kementrian Pendidikan RI. 1983. Kamus Besar Bahasa Indonesia (Depdikbud, 1983), Cet, 2, hal.179.

[5] Mohammad Hassan Falakmasir Shahrouz Moaven Hassan, Abolhassan, (2011) BI in E-Learning, International Journal of HumanComputer Studies, vol. 65, no. 2, pp. 125-149, 201

[6] Pressman, S, Roger., (2010), Software Engineering: A Practitioner's Approach, 7th edition. New York, The McGraw-Hill Company.

[7] Rahardja Untung, (2011) "Definisi iLearning". Raharja Enrichment Centre (REC). Tangerang.

[8] Rahardja Untung, Dewi Immaniar, (2014). iLearning Metode Efektif Untuk Sekolah Tinggi. Jurnal Perguruan Tinggi Rahaja ISSN: 1978 - 8282Vol.7 No.3 - Mei 2014. 